\title{
The conversion of certain microbially-derived cis- and trans-1,2- dihydrocatechols into various tetrahydro- and related-derivatives
}

\author{
Martin G. Banwell,* Alison J. Edwards, and David T. J. Loong \\ Research School of Chemistry, Institute of Advanced Studies, \\ The Australian National University, Canberra ACT 0200, Australia \\ E-mail: mgb@rsc.anu.edu.au
}

Dedicated to our colleague Professor Rod Rickards on the occasion of his $70^{\text {th }}$ birthday

(received 05 Feb 04; accepted 19 May 04; published on the web 28 May 04)

\begin{abstract}
The preparation of chirons 5-9 from the readily available and enantiomerically pure metabolites $\mathbf{1 - 4}$ is described.
\end{abstract}

Keywords: cis-1,2-Dihydrocatechols, Mitsunobu reaction, Kumada cross-coupling, CoreyWinter olefin synthesis

\section{Introduction}

As part of an ongoing program concerned with the exploitation of certain types of fermentation products in synthesis, ${ }^{1}$ we sought chemical methods for the conversion of the enantiomerically pure and C3-halogenated-cis-1,2-dihydrocatechols 1-3 into protected forms of various trans1,2,5,6-tetrahydro-derivatives such as 5-8. The ready availability of the homochiral trans-1,2dihydrocatechol 4 through manipulation of the shikimate-chorismate pathway using geneticallyengineered $E$. coli ${ }^{2}$ also prompted us to investigate related conversions of this compound.

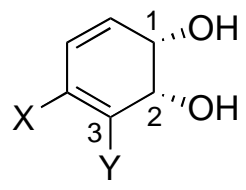

$1 \mathrm{X}=\mathrm{Br} \mathrm{Y}=\mathrm{I}$

$2 \mathrm{X}=\mathrm{H}, \mathrm{Y}=\mathrm{Cl}$

$3 \mathrm{X}=\mathrm{H}, \mathrm{Y}=\mathrm{I}$<smiles>O=C(O)C1=CC=C[C@H](O)C1O</smiles>

4 
Herein we detail the utilitarian procedures that have emerged from our studies on these matters and thus provided efficient access to compounds 5-9, species which we believe will serve as useful chirons in a wide-range of synthetic applications.<smiles></smiles>

5<smiles>ClC1=CCC[C@@H](O[SbH3])[C@@H]1O[SbH3]</smiles>

6<smiles>[M]O[C@H]1C(I)=CCC[C@@H]1O[M]#C</smiles>

7

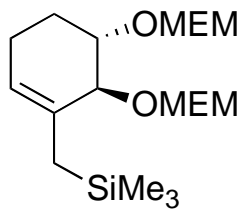

8<smiles>C=CC([O+]S)C(CCCCl)[O+]Sc1ccccc1</smiles>

9

\section{Results and Discussion}

Our initial studies focused on relevant chemical manipulations (Scheme 1) of the cis-1,2dihydrocatechol 1, a material readily derived by microbial dihydroxylation of $o$-bromoiodobenzene using a genetically engineered strain [JM109 (pDTG601)] of E. coli which over-expresses the responsible enzyme, viz. toluene dioxygenase (TDO). ${ }^{3,4}$ Thus, reaction of substrate 1 with diimide generated from potassium azodicarboxylate and acetic acid ${ }^{5}$ resulted in removal of the less-substituted double bond and the product of this process was then reductively de-iodinated using dihydrogen in the presence of $\mathrm{Pd}$ on $\mathrm{C}$ and quinoline to afford the crystalline diol 10 (67\% over two steps).



Scheme 1. (i) potassium azodicarboxylate (5.6 mole equiv.), acetic acid (11.5 mole equiv.), methanol, $18{ }^{\circ} \mathrm{C}, 34 \mathrm{~h}$; (ii) $\mathrm{H}_{2}$ (1 atm.), 10\% $\mathrm{Pd}$ on $\mathrm{C}(5 \mathrm{wt} \%), \mathrm{NaOAc}^{\circ} 3 \mathrm{H}_{2} \mathrm{O}, 1$ : $99 \mathrm{v} / \mathrm{v}$ quinoline-methanol, $18{ }^{\circ} \mathrm{C}, 36 \mathrm{~h}$; (iii) $p-\mathrm{O}_{2} \mathrm{NC}_{6} \mathrm{H}_{4} \mathrm{CO}_{2} \mathrm{H}$ (3.5 mole equiv.), diisopropyl azodicarboxylate (DIAD) (1.6 mole equiv.), $\mathrm{PPh}_{3}$ (1.8 mole equiv.), dichloromethane, $0-18{ }^{\circ} \mathrm{C}$, $15 \mathrm{~h}$; (iv) $\mathrm{K}_{2} \mathrm{CO}_{3}$ (2.3 mole equiv.), methanol, $18^{\circ} \mathrm{C}$, $1 \mathrm{~h}$; (v) TBS-Cl (4 mole equiv.), imidazole (8.9 mole equiv.), DMF, $18{ }^{\circ} \mathrm{C}, 3 \mathrm{~h}$.

The racemic modification of compound $\mathbf{1 0}$ has been reported previously. ${ }^{6}$ Selective inversion of the allylic hydroxy group within diol $\mathbf{1 0}$ was achieved using Mitsunobu chemistry in the same manner as described by Boyd et al. ${ }^{7}$ and employing $p$-nitrobenzoic acid as nucleophile. In this way the trans-diol mono-ester 11 was obtained. The spectral data obtained on this material were 
fully consistent with the assigned structure, further support for which arises from a single-crystal X-ray analysis of a congener prepared in an analogous manner (see below). Saponification of compound 11 was achieved with potassium carbonate in methanol and thus producing the transdiol 12 (83\% from 10), the racemic form of which has also been reported previously. ${ }^{6}$ Diol 12 was then converted into the target bis-tert-butyldimethylsilyl (TBS) ether 5 (75\%) under standard conditions.

cis-1,2-Dihydrocatechol 2, obtained via TDO-mediated dihydroxylation of chlorobenzene, ${ }^{4}$ was reduced (Scheme 2) to the tetrahydro-derivative $13^{8}(75 \%)$ using dihydrogen in the presence of rhodium on alumina ${ }^{8,9}$ and the latter compound then subjected to Mitsunobu reaction with $p$ nitrobenzoic acid. The resulting ester $14(78 \%)$ was hydrolysed to give the crystalline trans-diol $15(100 \%)$, the structure (including absolute stereochemistry) of which was confirmed by singlecrystal X-ray diffraction analysis (see Figure 1 and Experimental Section). As with congener 12, compound 15 was converted into the corresponding bis-TBS ether 6 (100\%) using standard methods.

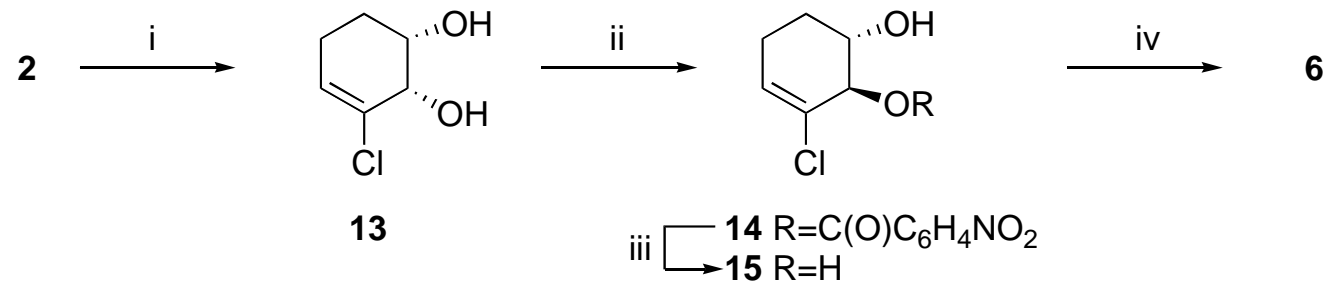

Scheme 2. (i) $\mathrm{H}_{2}$ (1 atm.), $5 \% \mathrm{Rh}$ on $\mathrm{Al}_{2} \mathrm{O}_{3}, 18{ }^{\circ} \mathrm{C}, 1.5 \mathrm{~h}$; (ii) $p-\mathrm{O}_{2} \mathrm{NC}_{6} \mathrm{H}_{4} \mathrm{CO}_{2} \mathrm{H}$ (3.0 mole equiv.), diethyl azodicarboxylate (DEAD) (1.4 mole equiv.), $\mathrm{PPh}_{3}$ (1.5 mole equiv.), toluene, $0_{-}$ $18{ }^{\circ} \mathrm{C}, 17 \mathrm{~h}$; (iii) $\mathrm{K}_{2} \mathrm{CO}_{3}$ (4.0 mole equiv.), methanol, $18{ }^{\circ} \mathrm{C}, 0.5 \mathrm{~h}$; (iv) TBS-Cl (4 mole equiv.), imidazole (12 mole equiv.), DMF, $18^{\circ} \mathrm{C}, 20 \mathrm{~h}$.

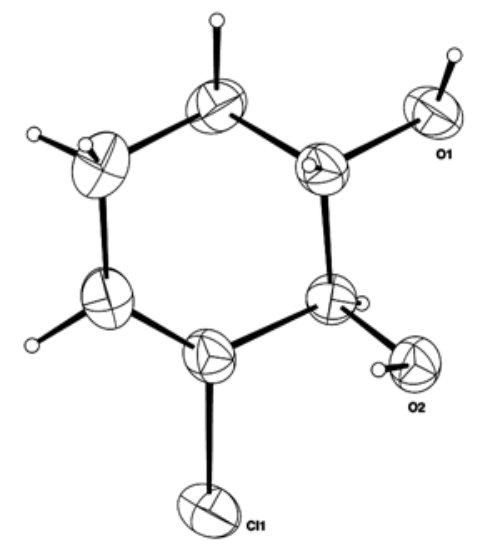

Figure 1. Anisotropic displacement ellipsoid plot $^{10}$ (with $50 \%$ probability ellipsoids) of one molecule of compound $\mathbf{1 5}$ derived from X-ray crystallographic data. 
The enantiomerically pure cis-1,2-dihydrocatechol (3) derived from microbial dihydroxylation of iodobenzene ${ }^{4}$ was converted (Scheme 3) into the corresponding and previously reported $^{7}$ tetrahydrocatechol 16 (99\%) using diimide generated in the same manner as described above for the conversion $1 \rightarrow \mathbf{1 0}$. Subjection of diol 16 to the by now standard Mitsunobu reaction conditions with $p$-nitrobenzoic acid afforded mono-ester 17 which was converted into the trans-diol 18 (70\% from 16) using potassium carbonate in methanol. This last compound was transformed into the corresponding bis-MEM ether 7 (100\%) upon reaction with MEM-chloride in the presence of Hünig's base. Compound 7 participates effectively in a Ni[0]catalysed Kumada cross-coupling reaction ${ }^{11}$ with trimethylsilylmethyl magnesium chloride to give the allylic silane 8 (93\% at 59\% conversion).

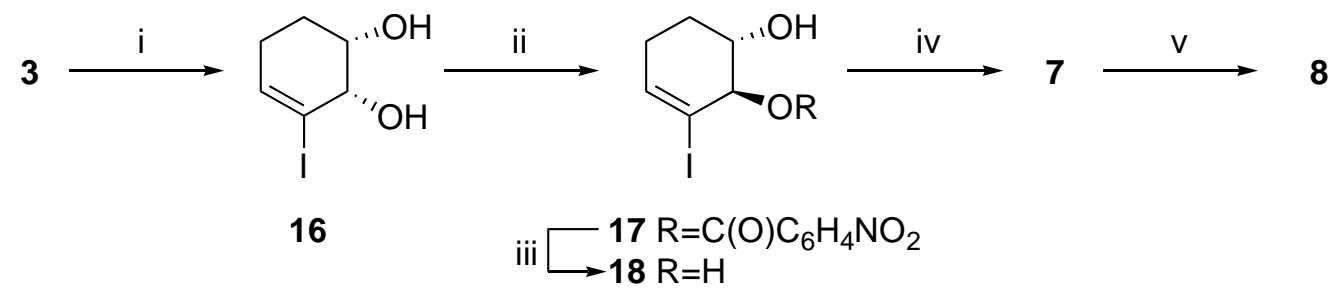

Scheme 3. (i) potassium azodicarboxylate (6.0 mole equiv.), acetic acid (12 mole equiv.), methanol, $18{ }^{\circ} \mathrm{C}, 1.5 \mathrm{~h}$; (ii) $p-\mathrm{O}_{2} \mathrm{NC}_{6} \mathrm{H}_{4} \mathrm{CO}_{2} \mathrm{H}$ (2.8 mole equiv.), DEAD (1.4 mole equiv.), $\mathrm{PPh}_{3}$ (1.6 mole equiv.), toluene, $0-18{ }^{\circ} \mathrm{C}, 21 \mathrm{~h}$; (iii) $\mathrm{K}_{2} \mathrm{CO}_{3}$ (1.6 mole equiv.), methanol, $18{ }^{\circ} \mathrm{C}, 0.5 \mathrm{~h}$; (iv) $\mathrm{MEM}-\mathrm{Cl}$ (15 mole equiv.), Hünig's base (15 mole equiv.), dichloromethane, $0-18{ }^{\circ} \mathrm{C}, 24 \mathrm{~h}$; (v) $\mathrm{Me}_{3} \mathrm{SiCH}_{2} \mathrm{MgCl}$ (2.0 mole equiv.), $\mathrm{Ni}(\mathrm{dppp}) \mathrm{Cl}_{2}(5 \mathrm{~mole} \%)$, toluene, $0-50{ }^{\circ} \mathrm{C}, 16 \mathrm{~h}$.

The chemical conversion of the trans-dihydrocatechol $\mathbf{4}$ into the open-chain chiron 9 is outlined in Scheme 4. The sequence begins with the three-step conversion of substrate 4 into the hydroxymethylated system 19 according to the procedure of Mueller et al. ${ }^{2}$ The latter compound was then subjected to reduction of the less-substituted double-bond using diimide and the resulting tetrahydrocatechol 20 (74\%) underwent ozonolytic cleavage and upon reduction of the resulting ozonide with sodium borohydride a chromatographically separable mixture of the C2 epimeric forms of triol 21 (86\% of a 5:2 mixture) was obtained. The major epimer was efficiently converted into the corresponding thiocarbonate $22(60 \%)$ by reaction with thiophosgene in the presence of DMAP as catalyst. Unexpectedly, thiocarbonate formation was accompanied by conversion of the C7-hydroxyl group within substrate 21 into the corresponding chloride, as seen in product 22. In the final step of the reaction sequence the major epimeric form of compound 22 was treated with 1,3-dimethyl-2-phenyl-1,3,2-diazaphospholidine at $40{ }^{\circ} \mathrm{C}$, thus effecting a Corey-Winter olefination reaction ${ }^{12}$ and thereby delivering the targeted chloroalkene 9 in $63 \%$ yield. 


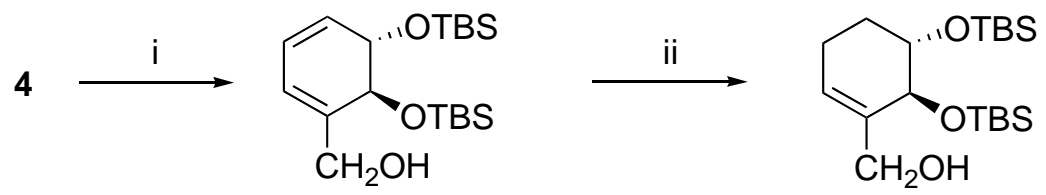

19

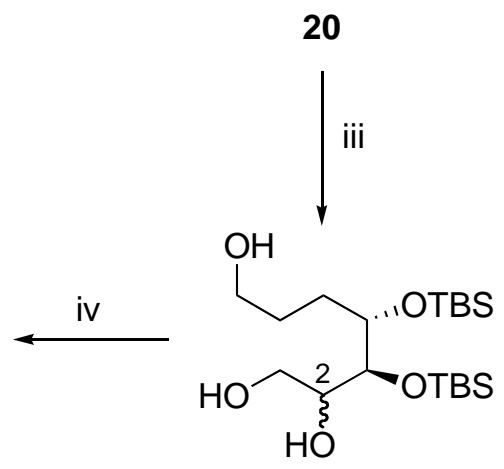

22

21

Scheme 4. (i) See reference 2; (ii) potassium azodicarboxylate (5.0 mole equiv.), acetic acid (9.7 mole equiv.), methanol, $18{ }^{\circ} \mathrm{C}, 1 \mathrm{~h}$; (iii) $\mathrm{O}_{3}$ (excess), methanol, $-78{ }^{\circ} \mathrm{C}, 0.25 \mathrm{~h}$ then $\mathrm{NaBH}_{4}(4.1$ mole equiv.), ca. $0{ }^{\circ} \mathrm{C}, 0.5 \mathrm{~h}$; (iv) thiophosgene (3.1 mole equiv.), DMAP (6.0 mole equiv.), chloroform, $0{ }^{\circ} \mathrm{C}, 1 \mathrm{~h}$; (v) 1,3-dimethyl-2-phenyl-1,3,2-diazaphospholidine (3.0 mole equiv.), $40{ }^{\circ} \mathrm{C}, 15 \mathrm{~h}$.

\section{Experimental Section}

General Procedures. Unless otherwise specified, proton $\left({ }^{1} \mathrm{H}\right)$ and carbon $\left({ }^{13} \mathrm{C}\right)$ NMR spectra were recorded on a Varian Gemini 300 or Varian Mercury 300 spectrometer operating at 300 $\mathrm{MHz}$ for proton and $75 \mathrm{MHz}$ for carbon nuclei. Chemical shifts were recorded as $\delta$ values in parts per million (ppm). Spectra were acquired in deuterochloroform $\left(\mathrm{CDCl}_{3}\right)$ at $20^{\circ} \mathrm{C}$ unless otherwise stated. For ${ }^{1} \mathrm{H}$ NMR spectra recorded in $\mathrm{CDCl}_{3}$, the peak due to residual $\mathrm{CHCl}_{3}(\delta$ 7.26) was used as the internal reference while the central peak $(\delta 77.0)$ of the $\mathrm{CDCl}_{3}$ triplet was used as the reference for proton-decoupled ${ }^{13} \mathrm{C}$ NMR spectra. ${ }^{1} \mathrm{H}$ NMR spectral data are recorded as follows: chemical shift $(\delta)$ [relative integral, multiplicity, coupling constant(s) $J(\mathrm{~Hz})$ ] where multiplicity is defined as: $\mathrm{s}=$ singlet; $\mathrm{d}=$ doublet; $\mathrm{t}=$ triplet; $\mathrm{q}=$ quartet or quintet; $\mathrm{m}=$ multiplet or combinations of the above. Infrared spectra $\left(v_{\max }\right)$ were recorded on either a Perkin-Elmer 1800 Fourier Transform Infrared Spectrophotometer or a Perkin-Elmer Spectrum One instrument. Samples were analyzed as $\mathrm{KBr}$ discs (for solids) or as thin films on $\mathrm{KBr}$ plates (for liquids/oils). Low and high resolution MS spectra were recorded on an AUTOSPEC spectrometer or a Kratos Analytical Concept ISQ instrument, the latter being located at the University of Tasmania. Optical rotations were determined on a Perkin-Elmer 241 polarimeter at the sodium D line $(598 \mathrm{~nm})$ using spectroscopic grade chloroform (unless otherwise specified) at $20{ }^{\circ} \mathrm{C}$ and at the concentrations $(c)(\mathrm{g} / 100 \mathrm{~mL})$ indicated. Measurements were carried out in a 
cell with a path length of $1 \mathrm{dm}$. Melting points (mp) were recorded on a Reichert hot-stage apparatus and are uncorrected. Elemental analyses were performed by the Australian National University Microanalytical Services Unit based in the Research School of Chemistry, The Australian National University, Canberra, Australia. Analytical thin layer chromatography (TLC) was conducted on aluminum-backed $0.2 \mathrm{~mm}$ thick silica gel 60 F254 plates (Merck) and the chromatograms were visualized under a $254 \mathrm{~nm}$ UV lamp and/or by treatment with an anisaldehyde-sulfuric acid-ethanol (3 mL: $4.5 \mathrm{~mL}: 200 \mathrm{~mL}$ ) dip or, occasionally, with a phosphomolybdic acid-ceric sulfate-sulfuric acid-water $(37.5 \mathrm{~g}: 7.5 \mathrm{~g}: 37.5 \mathrm{~mL}: 720 \mathrm{~mL})$ dip, followed by heating. The quoted retardation factors $\left(R_{\mathrm{f}}\right)$ have been rounded to the first decimal place. Flash chromatography was conducted according to the method of Still and co-workers ${ }^{13}$ using silica gel 60 (mesh size $0.040-0.063 \mathrm{~mm}$ ) as the stationary phase and the analytical reagent (AR) grade solvents indicated. Many starting materials and reagents were available from the Aldrich Chemical Company or EGA-Chemie and were used as supplied or, in the case of stable liquids, simply distilled. Drying agents and other inorganic salts were purchased from AJAX or BDH Chemicals. Reactions employing air- and/or moisture-sensitive reagents and intermediates were carried out under an atmosphere of dry, oxygen-free nitrogen in flame-dried apparatus. Diethyl ether was dried using sodium metal and then distilled, as required, from sodium benzophenone ketyl. Methanol was distilled from magnesium methoxide. Dichloromethane was distilled from calcium hydride and toluene from sodium metal. $N, N$-dimethylformamide (DMF) was heated at reflux over calcium hydride for $16 \mathrm{~h}$ then distilled and stored over $3 \AA$ molecular sieves. Organic solutions obtained from work-up of reaction mixtures were dried with magnesium sulfate $\left(\mathrm{MgSO}_{4}\right)$ then filtered and concentrated under reduced pressure on a rotary evaporator with the water bath temperature generally not exceeding $40{ }^{\circ} \mathrm{C}$.

\section{Synthetic Studies}

(1S,2R)-4-Bromo-3-cyclohexene-1,2-diol (10). A magnetically stirred slurry of diol $\mathbf{1}^{3}$ (3.33 g, $10.5 \mathrm{mmol})$ and potassium azodicarboxylate $(11.5 \mathrm{~g}, 59 \mathrm{mmol})$ in methanol $(100 \mathrm{~mL})$ maintained at $18{ }^{\circ} \mathrm{C}$ under a nitrogen atmosphere was treated dropwise with glacial acetic acid $(6.9 \mathrm{~mL}, 121$ $\mathrm{mmol})$. Two additional portions of potassium azodicarboxylate $(4.11 \mathrm{~g}, 21.1 \mathrm{mmol}$ and $11.7 \mathrm{~g}$, $60.2 \mathrm{mmol})$ and glacial acetic acid $(2.5 \mathrm{~mL}$ and $10 \mathrm{~mL})$ were added at the $10 \mathrm{~h}$ and $12 \mathrm{~h}$ marks and the resulting slurry stirred for a total of $34 \mathrm{~h}$ then quenched with $\mathrm{NaHCO}_{3}(20 \mathrm{~mL}$ of a saturated aq solution). The separated aqueous phase was extracted with dichloromethane $(3 \times 30$ $\mathrm{mL})$. The combined organic phases were then washed with water $(1 \times 20 \mathrm{~mL})$ and brine $(1 \times 20$ $\mathrm{mL}$ ) the latter causing precipitation of a flocculent white solid. This solid was removed by filtration and re-dissolved in methanol $(10 \mathrm{~mL})$ then the combined organic phases were dried $\left(\mathrm{MgSO}_{4}\right)$, filtered and concentrated under reduced pressure to give (1S,2R)-4-bromo-3-iodo-3cyclohexene-1,2-diol (2.35 g, 70\%) as a cream-colored solid (Found: $\mathrm{M}^{+\bullet}, 319.8732$. $\mathrm{C}_{6} \mathrm{H}_{8}{ }^{79} \mathrm{BrIO}_{2}$ requires 319.8732). $\delta_{\mathrm{H}} 4.36(1 \mathrm{H}, \mathrm{m}), 4.00(1 \mathrm{H}, \mathrm{m}), 2.88(1 \mathrm{H}, \mathrm{m}), 2.63(1 \mathrm{H}, \mathrm{m})$, $2.04(1 \mathrm{H}, \mathrm{m}), 1.88(1 \mathrm{H}, \mathrm{m})$ signals due to $-\mathrm{OH}$ protons not detected; $m / z 320$ and $318\left(\mathrm{M}^{+\bullet}\right.$, both 
14\%), 274 and 276 (both 64\%), $239\left[(\mathrm{M}-\mathrm{Br} \cdot)^{+}, 74 \%\right], 194$ (100). This material was used immediately in the next step of the reaction sequence.

$(1 S, 2 R)$-4-Bromo-3-iodo-3-cyclohexene-1,2-diol (2.35 g, $7.41 \mathrm{mmol})$ was dissolved in quinoline-methanol $(150 \mathrm{~mL}$ of a $1: 99 \mathrm{v} / \mathrm{v}$ mixture) and the resulting solution treated sequentially with $10 \% \mathrm{Pd}$ on $\mathrm{C}(480 \mathrm{mg}, 5 \mathrm{wt} \%)$ and $\mathrm{NaOAc}^{\circ} 3 \mathrm{H}_{2} \mathrm{O}(9.30 \mathrm{~g}, 2.8 \mathrm{mmol})$. The ensuing slurry was stirred vigorously at $18{ }^{\circ} \mathrm{C}$ under dihydrogen ( 1 atmosphere) for $36 \mathrm{~h}$ at which time TLC analysis indicated the complete consumption of starting material. The slurry was filtered through Celite ${ }^{\mathrm{TM}}$, Merck Type 60 silica gel $(\sim 2 \mathrm{~g})$ was then added to the filtrate and the resulting mixture concentrated under reduced pressure to give a free-flowing grey powder. This powder was loaded onto the top of a flash chromatography column which was eluted with ethyl acetate-hexane $\left(2: 3 \mathrm{v} / \mathrm{v}\right.$ mixture). Concentration of the relevant fractions $\left(R_{\mathrm{f}} 0.3\right.$ in $7: 3$ $\mathrm{v} / \mathrm{v}$ ethyl acetate-hexane) then gave the title compound $10(1.38 \mathrm{~g}, 95 \%)$ as an off-white solid, mp $89{ }^{\circ} \mathrm{C},[\alpha]_{\mathrm{D}}-65.6$ (c 0.8) (Found: $\mathrm{M}^{+}$, 191.9780; C, 37.40; H, 4.71; Br, 41.13. $\mathrm{C}_{6} \mathrm{H}_{9}{ }^{79} \mathrm{BrO}_{2}$ requires 191.9786; C, 37.33; $\mathrm{H}, 4.70 ; \mathrm{Br}, 41.39 \%$ ). $v_{\max }($ film, $\mathrm{NaCl}) / \mathrm{cm}^{-1} 3292,2924,1644$, $1427,1350,1273,1085,1004,852 ; \delta_{\mathrm{H}} 6.07(1 \mathrm{H}, \mathrm{m}), 4.16(1 \mathrm{H}, \mathrm{m}), 3.90(1 \mathrm{H}, \mathrm{m}), 2.63(1 \mathrm{H}, \mathrm{m})$, $2.47(1 \mathrm{H}, \mathrm{m}), 1.98(1 \mathrm{H}, \mathrm{m}), 1.81(1 \mathrm{H}, \mathrm{m})$, signals due to $-\mathrm{OH}$ protons not detected; $\delta_{\mathrm{C}} 128.6$ $(\mathrm{CH}), 127.0(\mathrm{C}), 68.2(\mathrm{CH}), 67.1(\mathrm{CH}), 32.9\left(\mathrm{CH}_{2}\right), 27.6\left(\mathrm{CH}_{2}\right) ; m / z 194$ and $192\left(\mathrm{M}^{+\bullet}\right.$, both $<1 \%), 150$ and 148 [(M-HOCHCH$\left.)^{+\bullet}, 82 \%\right], 113$ (80), 95 (15), 69 (100).

(1S,2S)-4-Bromo-3-cyclohexene-1,2-diol (12). A magnetically stirred slurry of cis-diol 10 (22 $\mathrm{mg}, 0.10 \mathrm{mmol})$ in dichloromethane $(1.2 \mathrm{~mL})$ maintained under a nitrogen atmosphere at $0{ }^{\circ} \mathrm{C}$ was treated with $p$-nitrobenzoic acid $(58 \mathrm{mg}, 0.35 \mathrm{mmol})$ and triphenylphosphine $(46 \mathrm{mg}, 0.18$ mmol). After the dropwise addition of DIAD $(32 \mu \mathrm{L}, 0.16 \mathrm{mmol})$ the reaction mixture was allowed to warm to $18{ }^{\circ} \mathrm{C}$ over $15 \mathrm{~h}$ then quenched with $\mathrm{NaHCO}_{3}(1 \mathrm{~mL}$ of a saturated aq solution). The separated aqueous layer was extracted with diethyl ether $(4 \times 5 \mathrm{~mL})$ and the combined organic phases washed with $\mathrm{NH}_{4} \mathrm{Cl}(1 \times 1 \mathrm{~mL}$ of a saturated aq solution), water $(1 \times 1$ $\mathrm{mL})$ and brine $(1 \times 1 \mathrm{~mL})$ before being dried $\left(\mathrm{MgSO}_{4}\right)$, filtered and concentrated under reduced pressure to give a viscous yellow residue. The bulk of this material was used immediately in the next step of the reaction sequence. Subjection of a small portion of this material to preparative TLC ( $1: 1 \mathrm{v} / \mathrm{v}$ ethyl acetate-hexane elution) and extraction of the appropriate band $\left(R_{\mathrm{f}} 0.5\right)$ provided an analytically pure sample of nitrobenzoate 11 as a clear, light-yellow oil, $[\alpha]_{\mathrm{D}}+7.7(c$ 1.2) [Found: $(\mathrm{M}-\mathrm{H} \cdot)^{+}, 339.9810 . \mathrm{C}_{13} \mathrm{H}_{12}{ }^{79} \mathrm{BrNO}_{3}$ requires 339.9820]. $v_{\max }$ (film, $\left.\mathrm{NaCl}\right) / \mathrm{cm}^{-1}$ $3435,1723,1527,1346,1270,1104,719 ; \delta_{\mathrm{H}} 8.26(4 \mathrm{H}, \mathrm{ABq}, J=4.0 \mathrm{~Hz}), 6.06(1 \mathrm{H}, \mathrm{m}), 5.43$ $(1 \mathrm{H}, \mathrm{m}), 4.09(1 \mathrm{H}, \mathrm{m}), 2.67(2 \mathrm{H}, \mathrm{m}), 2.34(1 \mathrm{H}, \mathrm{br} \mathrm{s}), 2.05(2 \mathrm{H}, \mathrm{m}) ; \delta_{\mathrm{C}} 164.5(\mathrm{C}), 150.6(\mathrm{C})$, $134.9(\mathrm{C}), 130.8(2 \times \mathrm{CH}), 128.0(\mathrm{C}), 124.8(2 \times \mathrm{CH}), 123.5(\mathrm{CH}), 76.4(\mathrm{CH}), 68.3(\mathrm{CH}), 33.1$ $\left(\mathrm{CH}_{2}\right), 29.3\left(\mathrm{CH}_{2}\right) ; \mathrm{m} / z 342$ and $340\left[(\mathrm{M}-\mathrm{H} \cdot)^{+}\right.$, both $<1 \%$ ], 325 and $323\left[\left(\mathrm{M}-\mathrm{H}_{2} \mathrm{O}\right)^{+\bullet}\right.$, both 37], 262 (10), 150 (100), 104 (45).

The bulk of the yellow oil obtained as described immediately above was dissolved in methanol $(2 \mathrm{~mL})$ and the resulting magnetically stirred solution was treated, in one portion, with potassium carbonate $(32 \mathrm{mg}, 0.23 \mathrm{mmol})$. Stirring was continued for $1 \mathrm{~h}$ at $18{ }^{\circ} \mathrm{C}$ whereupon TLC analysis indicated the complete consumption of starting material. Silica gel ( $20 \mathrm{mg}) \mathrm{was}$ 
therefore added and the ensuing mixture concentrated under reduced pressure to give a freeflowing white powder which was loaded onto the top of a flash chromatography column. Elution of the column with ethyl acetate-hexane (7:3 v/v mixture) and concentration of the relevant fractions $\left(R_{\mathrm{f}} 0.2\right.$ in $1: 1 \mathrm{v} / \mathrm{v}$ ethyl acetate-hexane) then gave the title compound 12 (16 mg, 83\% from cis-diol 10) as an off-white solid, mp 91-94 ${ }^{\circ} \mathrm{C}$ (Found: $\mathrm{M}^{+\bullet}, 191.9780 ; \mathrm{C}_{6} \mathrm{H}_{9}{ }^{79} \mathrm{BrO}_{2}$ requires 191.9786). $v_{\max }($ film, $\mathrm{NaCl}) / \mathrm{cm}^{-1} 3322,3300,2921,1648,1431,1299,1052,901 ; \delta_{\mathrm{H}}$ $6.15(1 \mathrm{H}, \mathrm{m}), 4.09(1 \mathrm{H}, \mathrm{m}), 3.85(1 \mathrm{H}, \mathrm{m}), 2.41(1 \mathrm{H}, \mathrm{d}, J=4.0 \mathrm{~Hz}), 2.36(1 \mathrm{H}, \mathrm{d}, J=3.2 \mathrm{~Hz}), 2.20$ $(2 \mathrm{H}, \mathrm{m}) 1.99(1 \mathrm{H}, \mathrm{m}), 1.84(1 \mathrm{H}, \mathrm{m}) ; \delta_{\mathrm{C}} 129.7(\mathrm{CH}), 124.5(\mathrm{C}), 74.0(\mathrm{CH}), 71.9(\mathrm{CH}), 34.2$ $\left(\mathrm{CH}_{2}\right), 29.3\left(\mathrm{CH}_{2}\right) ; \mathrm{m} / \mathrm{z} 194$ and $192\left(\mathrm{M}^{+\bullet}\right.$, both <1\%), 150 and 148 (both 91), 113 (80), 95 (28), 69 (100).

\section{\{[(1S,2S)-5-Bromo-5-cyclohexene-1,2-diyl]bis(oxy)\}bis[(1,1-dimethylethyl)dimethyl-silane}

(5). A magnetically stirred solution of trans-diol 12 (38 mg, $0.20 \mathrm{mmol})$, TBS-Cl (164 mg, 1.09 $\mathrm{mmol})$ and imidazole (166 mg, $2.44 \mathrm{mmol})$ in DMF $(330 \mu \mathrm{L})$ was maintained under a nitrogen atmosphere at $18{ }^{\circ} \mathrm{C}$ for $3 \mathrm{~h}$ whereupon TLC analysis indicated the absence of starting material. $\mathrm{NH}_{4} \mathrm{Cl}$ (1 mL of a saturated aq solution) was therefore added to quench the reaction mixture and the separated aqueous layer extracted with diethyl ether $(3 \times 5 \mathrm{~mL})$. The combined organic phases were washed with $\mathrm{NaHCO}_{3}(1 \times 5 \mathrm{~mL}$ of a saturated aq solution), water $(1 \times 2 \mathrm{~mL})$ and brine $(1 \times 2 \mathrm{~mL})$ before being dried $\left(\mathrm{MgSO}_{4}\right)$, filtered and concentrated under reduced pressure to give a yellow oil. Filtration of this oil through a short pad of Merck Type 60 silica gel (hexane elution) and concentration of the filtrate under reduced pressure gave the title compound 5 (63 $\mathrm{mg}, 75 \%)$ as a clear, colorless oil, $[\alpha]_{\mathrm{D}}+74.3$ (c 2.2) [Found: $\left(\mathrm{M}-\mathrm{C}_{4} \mathrm{H}_{9}\right)^{+}, 363.0813$. $\mathrm{C}_{14} \mathrm{H}_{28}{ }^{79} \mathrm{BrO}_{2} \mathrm{Si}_{2}$ requires 363.0811]. $v_{\max }$ (film, $\left.\mathrm{NaCl}\right) / \mathrm{cm}^{-1}$ 2954, 2932, 2891, 2858, 1649, 1468, $1255,1088,833,775 ; \delta_{\mathrm{H}} 5.88(1 \mathrm{H}, \mathrm{m}), 3.91(1 \mathrm{H}, \mathrm{m}), 3.72(1 \mathrm{H}, \mathrm{m}), 2.57(1 \mathrm{H}, \mathrm{m}), 2.38(1 \mathrm{H}, \mathrm{m})$, $1.95(1 \mathrm{H}, \mathrm{m}), 1.65(1 \mathrm{H}, \mathrm{m}), 0.90(9 \mathrm{H}, \mathrm{s}), 0.89(9 \mathrm{H}, \mathrm{s}), 0.09(4)(3 \mathrm{H}, \mathrm{s}), 0.08(9)(3 \mathrm{H}, \mathrm{s}), 0.07(6 \mathrm{H}$, s); $\delta_{\mathrm{C}} 129.1(\mathrm{CH}), 125.5(\mathrm{C}), 72.2(\mathrm{CH}), 70.5(\mathrm{CH}), 32.2\left(\mathrm{CH}_{2}\right), 28.4\left(\mathrm{CH}_{2}\right), 26.0\left(3 \times \mathrm{CH}_{3}\right), 25.9$ $\left(3 \times \mathrm{CH}_{3}\right), 18.2(\mathrm{C}), 18.1(\mathrm{C}),-4.41\left(2 \times \mathrm{CH}_{3}\right),-4.39\left(\mathrm{CH}_{3}\right),-4.6\left(\mathrm{CH}_{3}\right) ; m / z$ (LSIMS) 365 and $363\left[\left(\mathrm{M}-\mathrm{C}_{4} \mathrm{H}_{9} \cdot\right)^{+}\right.$, both ca. 40\%], 289 (45), 207 (100).

(1S,2S)-3-Chloro-3-cyclohexene-1,2-diol (13). 5\% Rh on alumina (1.20 g, $7 \mathrm{~mol} \%)$ was added to a magnetically stirred solution of diol 2 (10.4 g, $71 \mathrm{mmol})$ in absolute ethanol $(350 \mathrm{~mL})$, a balloon of dihydrogen was attached and the reaction vessel was evacuated then flushed three times with dihydrogen. The resulting black slurry was stirred at $18{ }^{\circ} \mathrm{C}$ under an atmosphere of dihydrogen for $1.5 \mathrm{~h}$ whereupon TLC analysis indicated the absence of starting material. As a consequence, the reaction mixture was filtered through a pad of Celite and the filtrate concentrated under reduced pressure to give an off-white solid. This material was subject to flash chromatography $(2: 15: 3 \mathrm{v} / \mathrm{v} / \mathrm{v}$ methanol-diethyl ether-hexane elution) and concentration of the relevant fractions $\left(R_{\mathrm{f}} 0.3\right.$, diethyl ether) gave the title compound $13^{8}(7.90 \mathrm{~g}, 75 \%)$ as white crystals, mp $115-116^{\circ} \mathrm{C} ;[\alpha]_{\mathrm{D}}-174\left(c 0.3\right.$, methanol) (Found: $\mathrm{M}^{+\bullet}, 148.0292 ; \mathrm{C}, 48.64 ; \mathrm{H}, 6.15$; $\mathrm{Cl}, 23.93 . \mathrm{C}_{6} \mathrm{H}_{9}{ }^{35} \mathrm{ClO}_{2}$ requires 148.0291; C, 48.50; $\left.\mathrm{H}, 6.10 ; \mathrm{Cl}, 23.86 \%\right) . v_{\max }(\mathrm{film}, \mathrm{NaCl}) / \mathrm{cm}^{-1}$ 3270, 2932, 2834, 1651, 1462, 1432, 1356, 1332, 1295, 1124, 1096, 1054, 1002, 984, 923, 910, $820,787,690,591,459 ; \delta_{\mathrm{H}} 5.99(1 \mathrm{H}, \mathrm{dd}, J=3.5$ and $4.5 \mathrm{~Hz}), 4.16(1 \mathrm{H}, \mathrm{m}), 3.94(1 \mathrm{H}, \mathrm{dt}, J=3.5$ 
and $9.2 \mathrm{~Hz}), 2.70\left(2 \mathrm{H}\right.$, broad s), $2.31(1 \mathrm{H}, \mathrm{m}),, 2.11(1 \mathrm{H}, \mathrm{m}), 1.88-1.70(2 \mathrm{H}$, complex m$) ; \delta_{\mathrm{C}}$ $131.0(\mathrm{C}), 128.4(\mathrm{CH}), 70.5(\mathrm{CH}), 68.9(\mathrm{CH}), 25.2\left(\mathrm{CH}_{2}\right), 23.8\left(\mathrm{CH}_{2}\right)$; MS $(\mathrm{EI}) \mathrm{m} / z 150(2 \%)$ and $148\left(\mathrm{M}^{+}, 7\right), 106(45), 104(100)$.

(1R,6S)-2-Chloro-6-hydroxycyclohex-2-enyl 4-nitrobenzoate (14). A magnetically stirred slurry of diol 13 (140 mg, $0.945 \mathrm{mmol})$, p-nitrobenzoic acid (476 mg, $2.85 \mathrm{mmol}$ ) and triphenylphosphine $(374 \mathrm{mg}, 1.42 \mathrm{mmol})$ in toluene $(10 \mathrm{~mL})$ maintained at $0{ }^{\circ} \mathrm{C}$ under a nitrogen atmosphere was treated, dropwise, with DEAD $(219 \mu \mathrm{L}, 1.32 \mathrm{mmol})$. The resulting mixture was allowed to warm to $18{ }^{\circ} \mathrm{C}$ over $17 \mathrm{~h}$ then quenched with $\mathrm{NaHCO}_{3}(5 \mathrm{~mL}$ of a saturated aq solution) and the separated aqueous layer extracted with diethyl ether $(3 \times 10 \mathrm{~mL})$. The combined organic phases were washed with $\mathrm{NH}_{4} \mathrm{Cl}(1 \times 5 \mathrm{~mL}$ of a saturated aq solution $)$ and brine $(1 \times 5$ $\mathrm{mL})$ before being dried $\left(\mathrm{MgSO}_{4}\right)$, filtered and concentrated under reduced pressure to give a yellow paste. Subjection of this material to flash chromatography $(3: 97 \mathrm{v} / \mathrm{v}$ methanolchloroform elution) and concentration of the relevant fractions $\left(R_{\mathrm{f}} 0.7\right.$ in diethyl ether) then gave a viscous oil containing the desired compound but which was contaminated with significant amounts of triphenylphosphine oxide. Subjection of this material to further flash chromatography ( $2: 3 \mathrm{v} / \mathrm{v}$ ethyl acetate-hexane elution) and concentration of the relevant fractions under reduced pressure gave the title compound $14(219 \mathrm{mg}, 78 \%)$ as a dark-yellow and sticky gum, $[\alpha]_{\mathrm{D}}$ +133.3 (c 0.5) [Found: $\left(\mathrm{M}-\mathrm{H}_{2} \mathrm{O}\right)^{+\bullet}, 279.0299 . \mathrm{C}_{13} \mathrm{H}_{10}{ }^{35} \mathrm{ClNO}_{4}$ requires 279.0298]. $v_{\max }$ (film, $\mathrm{NaCl}) / \mathrm{cm}^{-1} 3435,2934,1728,1606,1528,1268,1102,718 ; \delta_{\mathrm{H}} 8.26(4 \mathrm{H}, \mathrm{m}), 6.20(1 \mathrm{H}, \mathrm{td}, J=$ 0.7 and $4.1 \mathrm{~Hz}), 5.52(1 \mathrm{H}, \mathrm{m}), 4.15(1 \mathrm{H}, \mathrm{m}), 2.65(1 \mathrm{H}$, br s$), 2.33(2 \mathrm{H}, \mathrm{m}), 1.93(2 \mathrm{H}, \mathrm{m}) ; \delta_{\mathrm{C}}$ $164.6(\mathrm{C}), 150.5(\mathrm{C}), 134.7(\mathrm{C}), 130.9(1)(2 \times \mathrm{CH}), 130.8(8)(2 \times \mathrm{CH}), 126.7(\mathrm{C}), 123.5(\mathrm{CH})$, $76.6(\mathrm{CH}), 69.8(\mathrm{CH}), 26.4\left(\mathrm{CH}_{2}\right), 22.7\left(\mathrm{CH}_{2}\right) ; m / z 299$ and $297\left(\mathrm{M}^{+}\right.$, both $\left.<1 \%\right), 281$ and 279 $\left[\left(\mathrm{M}-\mathrm{H}_{2} \mathrm{O}\right)^{+\bullet}, 7\right.$ and 21], $150(100)$.

(1S,2R)-3-Chloro-3-cyclohexene-1,2-diol (15). A magnetically stirred solution of nitrobenzoate $14(956 \mathrm{mg}, 3.22 \mathrm{mmol})$ in methanol $(50 \mathrm{~mL})$ was treated with anhydrous potassium carbonate (1.80 g, $13.0 \mathrm{mmol})$. Stirring was continued at $18{ }^{\circ} \mathrm{C}$ for $0.5 \mathrm{~h}$, then Merck Type 60 silica gel $(\sim 1 \mathrm{~g})$ was added and the reaction mixture concentrated under reduced pressure to give a freeflowing and light-yellow powder. Subjection of this material to flash chromatography $(1: 4: 5$ $\mathrm{v} / \mathrm{v} / \mathrm{v}$ methanol-hexane-diethyl ether elution) and concentration of the relevant fractions $\left(R_{\mathrm{f}} 0.3\right.$ in diethyl ether) then gave the title compound 15 (481 $\mathrm{mg}, 100 \%)$ as a white solid, mp 71$71.5^{\circ} \mathrm{C},[\alpha]_{\mathrm{D}}+116.6$ (c 0.7, methanol) (Found: $\mathrm{M}^{+\bullet}$, 148.0291; C, 48.52; H, 6.35; Cl, 23.48 . $\mathrm{C}_{6} \mathrm{H}_{9}{ }^{35} \mathrm{ClO}_{2}$ requires 148.0291; C, 48.50; H, 6.10; Cl, 23.86\%). $v_{\max }($ film, $\mathrm{NaCl}) / \mathrm{cm}^{-1} 3349$, $2927,1649,1435,1334,1286,1168,1069,1040,1000,970,933,883,832,771 ; \delta_{\mathrm{H}} 5.92(1 \mathrm{H}$, tm, $J=4.0 \mathrm{~Hz}), 4.05(1 \mathrm{H}$, br m), $3.83(1 \mathrm{H}, \mathrm{m}), 3.20(2 \mathrm{H}$, br s), $2.20(2 \mathrm{H}, \mathrm{m}), 1.95(1 \mathrm{H}, \mathrm{m}), 1.72$ $(1 \mathrm{H}, \mathrm{m}) ; \delta_{\mathrm{C}} 131.4(\mathrm{C}), 127.3(\mathrm{CH}), 74.8(\mathrm{CH}), 72.7(\mathrm{CH}), 27.5\left(\mathrm{CH}_{2}\right), 23.8\left(\mathrm{CH}_{2}\right) ; \mathrm{m} / \mathrm{z} 150$ and $148\left(\mathrm{M}^{+}, 2\right.$ and 6\%), $106(50), 104$ (100).

\section{\{[(1S,2R)-3-Chloro-3-cyclohexene-1,2-diyl]bis(oxy)\}bis[(1,1-dimethylethyl)dimethyl-silane}

(6). A magnetically stirred solution of trans-diol 15 (477 mg, $3.22 \mathrm{mmol})$, TBS-Cl (1.95 g, 12.9 mmol) and imidazole (2.64 g, $38.6 \mathrm{mmol})$ in DMF $(5.4 \mathrm{~mL})$ was maintained under a nitrogen atmosphere at $18{ }^{\circ} \mathrm{C}$ for $20 \mathrm{~h}$ whereupon TLC analysis indicated the absence of starting material. 
As a consequence, $\mathrm{NaHCO}_{3}(5 \mathrm{~mL}$ of a saturated aq solution) was added to the reaction mixture and the separated aqueous layer extracted with diethyl ether $(3 \times 5 \mathrm{~mL})$. The combined organic phases were washed with $\mathrm{NH}_{4} \mathrm{Cl}(1 \times 5 \mathrm{~mL}$ of a saturated aq solution $)$ and brine $(1 \times 5 \mathrm{~mL})$ before being dried $\left(\mathrm{MgSO}_{4}\right)$, filtered and concentrated under reduced pressure to give a yellow oil. Subjection of this material to flash chromatography (hexane elution) and concentration of the relevant fractions $\left(R_{\mathrm{f}} 0.7\right.$ in $5: 95 \mathrm{v} / \mathrm{v}$ ethyl acetate-hexane) then gave the title compound 6 $(1.61 \mathrm{~g}, 100 \%)$ as a clear, colorless oil, $[\alpha]_{\mathrm{D}}+86.1$ (c 3.6) [Found: $\left(\mathrm{M}-\mathrm{CH}_{3}\right)^{+}, 361.1781$. $\mathrm{C}_{18} \mathrm{H}_{37}{ }^{35} \mathrm{ClO}_{2} \mathrm{Si}_{2}$ requires 361.1786]. $v_{\max }($ film, $\mathrm{NaCl}) / \mathrm{cm}^{-1} 2953,2932,2894,2858,1654,1468$, 1364, 1254, 1089, 1008, 890, 837, 776; $\delta_{\mathrm{H}} 5.92(1 \mathrm{H}, \mathrm{dd}, J=2.3$ and $5.4 \mathrm{~Hz}), 3.91(1 \mathrm{H}, \mathrm{m}), 3.77$ $(1 \mathrm{H}, \mathrm{m}), 2.31(1 \mathrm{H}, \mathrm{m}), 2.00(1 \mathrm{H}, \mathrm{dt}, J=5.6$ and $18 \mathrm{~Hz}), 1.83(1 \mathrm{H}, \mathrm{m}), 1.60(1 \mathrm{H}, \mathrm{m}), 0.93(9 \mathrm{H}, \mathrm{s})$, $0.89(9 \mathrm{H}, \mathrm{s}), 0.19(3 \mathrm{H}, \mathrm{s}) 0.15(3 \mathrm{H}, \mathrm{s}) 0.09(3 \mathrm{H}, \mathrm{s}), 0.08(3 \mathrm{H}, \mathrm{s}) ; \delta_{\mathrm{C}} 131.2(\mathrm{C}), 127.3(\mathrm{CH}), 74.0$ $(\mathrm{CH}), 71.8(\mathrm{CH}), 25.9\left(3 \times \mathrm{CH}_{3}\right), 25.8\left(3 \times \mathrm{CH}_{3}\right), 23.6\left(\mathrm{CH}_{2}\right), 21.9\left(\mathrm{CH}_{2}\right), 18.2(\mathrm{C}), 18.1(\mathrm{C}),-$ $2.8\left(\mathrm{CH}_{3}\right),-4.2\left(\mathrm{CH}_{3}\right),-4.5(7)\left(\mathrm{CH}_{3}\right),-4.6(0)\left(\mathrm{CH}_{3}\right) ; \mathrm{m} / z 363$ and $361\left[\left(\mathrm{M}-\mathrm{CH}_{3}\right)^{+},<1\right.$ and $2 \%$ ], 321 and $319\left[\left(\mathrm{M}-\mathrm{C}_{4} \mathrm{H}_{9} \cdot\right)^{+}, 20\right.$ and 59], 218 (33), 189 (53), 187 (51), 147 (100).

(1S,2S)-3-Iodo-3-cyclohexene-1,2-diol (16). A magnetically stirred slurry of diol 3 (1.52 g, 6.40 $\mathrm{mmol})$ and potassium azodicarboxylate $(7.50 \mathrm{~g}, 38.6 \mathrm{mmol})$ in methanol $(32 \mathrm{~mL})$ maintained at $18^{\circ} \mathrm{C}$ under a nitrogen atmosphere was treated dropwise with a glacial acetic acid $(4.4 \mathrm{~mL}, 76.9$ mmol). After $1.5 \mathrm{~h}$, the reaction mixture was concentrated under reduced pressure and the residue partitioned between water $(50 \mathrm{~mL})$ and ethyl acetate $(50 \mathrm{~mL})$. The separated aqueous layer was extracted with ethyl acetate $(3 \times 20 \mathrm{~mL})$ and the combined organic phases washed with $\mathrm{NaHCO}_{3}(3 \times 20 \mathrm{~mL})$ and brine $(1 \times 10 \mathrm{~mL})$ before being dried $\left(\mathrm{MgSO}_{4}\right)$, filtered and concentrated under reduced pressure to give the title compound $16^{7}(1.53 \mathrm{~g}, 99 \%)$ as an off-white solid, mp 97-99 ${ }^{\circ} \mathrm{C},[\alpha]_{\mathrm{D}}+50.6\left(c \quad 0.2, \mathrm{CHCl}_{3}\right)$ [Found: $\mathrm{M}^{+\bullet}, 239.9644 . \mathrm{C}_{6} \mathrm{H}_{9} \mathrm{IO}_{2}$ requires 239.9647]. $v_{\max }\left(\right.$ film, NaCl)/cm $\mathrm{cm}^{-1} 3368,2953,1644,1459,1427,1130,997,757 ; \delta_{\mathrm{H}} 6.51(1 \mathrm{H}$, $\mathrm{dd}, J=0.6$ and $3.7 \mathrm{~Hz}), 4.21(1 \mathrm{H}, \mathrm{m}), 3.97(1 \mathrm{H}, \mathrm{m}), 2.59(2 \mathrm{H}$, br s), $2.29(1 \mathrm{H}, \mathrm{m}), 2.09(1 \mathrm{H}, \mathrm{m})$, $1.85(2 \mathrm{H}, \mathrm{m}) ; \delta_{\mathrm{C}} 141.0(\mathrm{CH}), 98.9(\mathrm{C}), 73.9(\mathrm{CH}), 68.8(\mathrm{CH}), 27.0\left(\mathrm{CH}_{2}\right), 25.2\left(\mathrm{CH}_{2}\right) ; m / z 240$ $\left(\mathrm{M}^{+\bullet}, 29 \%\right), 196(100)$.

(1S,2R)-3-Iodo-3-cyclohexene-1,2-diol (18). A magnetically stirred slurry of cis-diol 16 (97.8 $\mathrm{mg}, 0.41 \mathrm{mmol}), p$-nitrobenzoic acid $(193 \mathrm{mg}, 1.15 \mathrm{mmol})$ and triphenylphosphine (169 $\mathrm{mg}$, $0.644 \mathrm{mmol})$ in toluene $(8 \mathrm{~mL})$ maintained under a nitrogen atmosphere at $0{ }^{\circ} \mathrm{C}$ was treated, dropwise, with DEAD (95 $\mu \mathrm{L}, 0.57 \mathrm{mmol})$. The ensuing mixture was allowed to warm to $18{ }^{\circ} \mathrm{C}$ over $21 \mathrm{~h}$ then quenched with $\mathrm{NaHCO}_{3}(5 \mathrm{~mL}$ of a saturated aq solution) and the separated aqueous layer extracted with diethyl ether $(3 \times 20 \mathrm{~mL})$. The combined organic phases were washed with brine $(1 \times 5 \mathrm{~mL})$ before being dried $\left(\mathrm{MgSO}_{4}\right)$, filtered and concentrated under reduced pressure to give a yellow paste. Subjection of this material to flash chromatography $\left(1: 3 \mathrm{v} / \mathrm{v}\right.$ ethyl acetate-hexane elution) and concentration of the relevant fractions $\left(R_{\mathrm{f}} 0.7\right.$ in diethyl ether) then gave a viscous oil containing the desired compound albeit contaminated with significant amounts of DEAD- $\mathrm{H}_{2}$. Subjection of a small portion of this material to further flash chromatography $(2: 98 \mathrm{v} / \mathrm{v}$ methanol-chloroform elution) gave spectroscopically pure nitrobenzoate 17 as a dark-yellow and sticky gum, $[\alpha]_{\mathrm{D}}+24.8$ (c 0.8) [Found: $\left(\mathrm{M}-\mathrm{H}_{2} \mathrm{O}\right)^{+\bullet}$, 
370.9655. $\mathrm{C}_{13} \mathrm{H}_{10} \mathrm{INO}_{4}$ requires 370.9655]. $v_{\max }($ film, $\mathrm{NaCl}) / \mathrm{cm}^{-1} 3436,2930,1726,1605,1526$, $1346,1266,1104,957,868,717 ; \delta_{\mathrm{H}} 8.25(4 \mathrm{H}, \mathrm{m}), 6.69(1 \mathrm{H}, \mathrm{td}, J=1.2$ and $4.0 \mathrm{~Hz}), 5.55(1 \mathrm{H}$, $\mathrm{m}), 4.08(1 \mathrm{H}, \mathrm{m}), 3.11\left(1 \mathrm{H}\right.$, br s), 2.42-2.16 (2H, complex m), 2.02-1.84 (2H, m); $\delta_{\mathrm{C}} 164.4(\mathrm{C})$, $150.5(\mathrm{C}), 143.3(\mathrm{CH}), 134.8(\mathrm{C}), 130.9(2 \times \mathrm{CH}), 123.4(2 \times \mathrm{CH}), 92.2(\mathrm{C}), 79.6(\mathrm{CH}), 69.8$ $(\mathrm{CH}), 26.7\left(\mathrm{CH}_{2}\right), 26.4\left(\mathrm{CH}_{2}\right) ; m / z 389\left(\mathrm{M}^{+\bullet},<1 \%\right), 371\left[\left(\mathrm{M}-\mathrm{H}_{2} \mathrm{O}\right)^{+\bullet},<1\right], 344(<1), 262(25)$, 150 (100).

A magnetically stirred solution of the abovementioned viscous oil in methanol $(3 \mathrm{~mL})$ was treated with $\mathrm{K}_{2} \mathrm{CO}_{3}(91 \mathrm{mg}, 0.66 \mathrm{mmol})$. Stirring was continued for $0.5 \mathrm{~h}$ whereupon TLC analysis indicated the complete consumption of starting material. As a consequence, silica gel ( $\sim 100 \mathrm{mg}$ ) was added to the reaction mixture which was then concentrated under reduced pressure to give a free-flowing and pinkish-grey powder. This was loaded onto the top of a flash chromatography column which was then eluted with ethyl acetate-hexane ( $7: 3 \mathrm{v} / \mathrm{v}$ mixture). Concentration of the relevant fractions $\left(R_{\mathrm{f}} 0.2\right.$ in $1: 1 \mathrm{v} / \mathrm{v}$ ethyl acetate-hexane) gave the title compound 18 (68 mg, 70\% from compound 16) as an off-white solid, mp $113{ }^{\circ} \mathrm{C},[\alpha]_{\mathrm{D}}+13.8(c$ 0.7) (Found: $\mathrm{M}^{+\bullet}, 239.9650 ; \mathrm{C}, 30.01 ; \mathrm{H}, 3.82 ; \mathrm{I}, 52.59 . \mathrm{C}_{6} \mathrm{H}_{9} \mathrm{IO}_{2}$ requires 239.9647; C, 30.02; $\mathrm{H}$, 3.78; I, 52.87\%). $v_{\max }($ film, $\mathrm{NaCl}) / \mathrm{cm}^{-1} 3325,2897,1430,1326,1049,880,818,739 ; \delta_{\mathrm{H}} 6.43$ $(1 \mathrm{H}, \mathrm{m}), 4.03(1 \mathrm{H}, \mathrm{m}), 3.85(1 \mathrm{H}, \mathrm{m}), 2.27(2 \mathrm{H}, \mathrm{br} \mathrm{s}), 2.18(2 \mathrm{H}, \mathrm{m}), 2.01(1 \mathrm{H}, \mathrm{m}), 1.85-1.70(1 \mathrm{H}$, complex m); $\delta_{\mathrm{C}} 139.8(\mathrm{CH}), 101.5(\mathrm{C}), 77.6(\mathrm{CH}), 72.1(\mathrm{CH}), 27.6\left(\mathrm{CH}_{2}\right), 27.4\left(\mathrm{CH}_{2}\right) ; m / z 240$ $\left(\mathrm{M}^{+\bullet}, 31 \%\right), 196(100)$.

(5S,6R)-1-Iodo-5,6-bis[(2-methoxyethoxy)methoxy]cyclohex-1-ene (7). A magnetically stirred slurry of trans-diol $18(320 \mathrm{mg}, 1.33 \mathrm{mmol})$ and diisopropylethylamine $(3.5 \mathrm{~mL}, 20.0 \mathrm{mmol})$ in dichloromethane $(3.3 \mathrm{~mL})$ maintained under a nitrogen atmosphere was cooled to $0{ }^{\circ} \mathrm{C}$ and infused with MEM-Cl $(2.3 \mathrm{~mL}, 20.0 \mathrm{mmol})$ using a syringe and with the associated needle projecting under the liquid surface. The resulting solution was allowed to warm to $18{ }^{\circ} \mathrm{C}$ over 24 $\mathrm{h}$ then quenched with $\mathrm{NH}_{4} \mathrm{Cl}$ ( $5 \mathrm{~mL}$ of a saturated aq solution). The separated aqueous layer was extracted with diethyl ether $(3 \times 10 \mathrm{~mL})$ and the combined organic phases then dried $\left(\mathrm{MgSO}_{4}\right)$, filtered and concentrated under reduced pressure to give a light-brown oil. Subjection of this material to flash chromatography $(1: 1 \mathrm{v} / \mathrm{v}$ ethyl acetate-hexane elution) and concentration of the relevant fractions $\left(R_{\mathrm{f}} 0.2\right)$ then gave the title compound $7(772 \mathrm{mg}, 100 \%)$ as a light-brown oil, $[\alpha]_{\mathrm{D}}+65.2$ (c 0.9 ) (Found: $\mathrm{M}^{+\bullet}, 416.0698 \quad \mathrm{C}_{14} \mathrm{H}_{25} \mathrm{IO}_{6}$ requires 416.0696). $v_{\max }$ (film, $\mathrm{NaCl}) / \mathrm{cm}^{-1} 2885,1453,1364,1107,1037,850 ; \delta_{\mathrm{H}} 6.58(1 \mathrm{H}, \mathrm{dd}, J=2.9$ and $4.9 \mathrm{~Hz}), 4.85(2 \mathrm{H}$, ABq, $J=7.8 \mathrm{~Hz}), 4.76(2 \mathrm{H}, \mathrm{ABq}, J=7.2 \mathrm{~Hz}), 4.07(1 \mathrm{H}, \mathrm{m}), 3.99-3.89$ (2H, complex m), 3.79$3.66(3 \mathrm{H}$, complex m), 3.60-3.51 (4H, complex m), 3.37(3) $(3 \mathrm{H}, \mathrm{s}), 3.36(7)(3 \mathrm{H}, \mathrm{s}), 2.26(1 \mathrm{H}$, m), $2.04(1 \mathrm{H}, \mathrm{m}), 1.85(2 \mathrm{H}, \mathrm{m}) ; \delta_{\mathrm{C}} 142.0(\mathrm{CH}), 95.7\left(\mathrm{CH}_{2}\right), 95.2(\mathrm{C}), 94.3\left(\mathrm{CH}_{2}\right), 79.9(\mathrm{CH})$, $74.5(\mathrm{CH}), 71.6\left(2 \times \mathrm{CH}_{2}\right), 67.7\left(\mathrm{CH}_{2}\right), 67.0\left(\mathrm{CH}_{2}\right), 59.0\left(2 \times \mathrm{CH}_{3}\right), 25.3\left(\mathrm{CH}_{2}\right), 21.4\left(\mathrm{CH}_{2}\right) ; \mathrm{m} / z$ $416\left(\mathrm{M}^{+\bullet}, 0.3 \%\right), 341(15), 89(100)$.

\{[(5S,6S)-5,6-Bis[(2-methoxyethoxy)methoxy]cyclohex-1-enyl]methyl\}trimethyl-silane (8). A magnetically stirred slurry of bis-MEM ether $7(554 \mathrm{mg}, 1.33 \mathrm{mmol})$ and $\mathrm{Ni}(\mathrm{dppp}) \mathrm{Cl}_{2}(36 \mathrm{mg}$, $0.07 \mathrm{mmol}, 5 \mathrm{~mol} \%)$ in toluene $(14 \mathrm{~mL})$ maintained under a nitrogen atmosphere was cooled to $0{ }^{\circ} \mathrm{C}$ and $\mathrm{ClMgCH}_{2} \mathrm{Si}\left(\mathrm{CH}_{3}\right)_{3}(2.7 \mathrm{~mL}$ of a $1 \mathrm{M}$ solution in THF, $2.7 \mathrm{mmol})$ added via syringe 
pump over $0.25 \mathrm{~h}$. The resulting deep-red solution was maintained at $0{ }^{\circ} \mathrm{C}$ for $1 \mathrm{~h}$, heated at 50 ${ }^{\circ} \mathrm{C}$ for $16 \mathrm{~h}$ then cooled to $18{ }^{\circ} \mathrm{C}$ and treated with $\mathrm{NH}_{4} \mathrm{Cl}(10 \mathrm{~mL}$ of a saturated aq solution). The separated aqueous layer was extracted with diethyl ether $(3 \times 10 \mathrm{~mL})$ and the combined organic phases washed with $\mathrm{NH}_{4} \mathrm{Cl}(1 \times 5 \mathrm{~mL}$ of a saturated aq solution), water $(1 \times 5 \mathrm{~mL})$ and brine $(1$ $\times 5 \mathrm{~mL}$ ) before being dried $\left(\mathrm{MgSO}_{4}\right)$, filtered and concentrated under reduced pressure to give a dark-brown oil. Subjection of this material to flash chromatography $(2: 3 \mathrm{v} / \mathrm{v}$ ethyl acetatehexane elution) provided two fractions, $\mathrm{A}$ and $\mathrm{B}$.

Concentration of fraction $\mathrm{A}\left(R_{\mathrm{f}} 0.4\right.$ in $1: 1 \mathrm{v} / \mathrm{v}$ ethyl acetate-hexane $)$ gave the title compound $8\left(275 \mathrm{mg}, 93 \%\right.$ at $59 \%$ conversion) as a clear, colorless oil, $[\alpha]_{\mathrm{D}}+24.5(c 0.7)$ (Found: $\mathrm{M}^{+\cdot}$, 376.2283. $\mathrm{C}_{18} \mathrm{H}_{36} \mathrm{O}_{6} \mathrm{Si}$ requires 376.2281). $v_{\max }(\mathrm{film}, \mathrm{NaCl}) / \mathrm{cm}^{-1} 2886,1246,1104,1034,848$; $\delta_{\mathrm{H}} 5.41(1 \mathrm{H}, \mathrm{m}), 4.85(1 \mathrm{H}, \mathrm{d}, J=7.0 \mathrm{~Hz}), 4.72(3 \mathrm{H}, \mathrm{m}), 3.90(1 \mathrm{H}, \mathrm{m}), 3.79(1 \mathrm{H}, \mathrm{m}), 3.71-3.61$ $(4 \mathrm{H}$, complex m), $3.54(4 \mathrm{H}, \mathrm{m}), 3.35(6 \mathrm{H}, \mathrm{s}), 2.12-1.91(2 \mathrm{H}$, complex m), $1.74(2 \mathrm{H}, \mathrm{m}), 1.49$ $(2 \mathrm{H}, \mathrm{ABq}, J=13.5 \mathrm{~Hz}),-0.01(9 \mathrm{H}, \mathrm{s}) ; \delta_{\mathrm{C}} 132.4(\mathrm{C}), 123.6(\mathrm{CH}), 95.6\left(\mathrm{CH}_{2}\right), 93.8\left(\mathrm{CH}_{2}\right), 76.9$ $(\mathrm{CH}), 73.8(\mathrm{CH}), 71.7\left(\mathrm{CH}_{2}\right), 71.6\left(\mathrm{CH}_{2}\right), 67.3\left(\mathrm{CH}_{2}\right), 66.7\left(\mathrm{CH}_{2}\right), 58.9(1)\left(\mathrm{CH}_{3}\right), 58.8(9)\left(\mathrm{CH}_{3}\right)$, $23.5\left(\mathrm{CH}_{2}\right), 22.6\left(\mathrm{CH}_{2}\right), 21.4\left(\mathrm{CH}_{2}\right),-1.2\left(3 \times \mathrm{CH}_{3}\right) ; \mathrm{m} / z 376\left(\mathrm{M}^{+\bullet},<1 \%\right), 300(3), 244(30), 194$ (25), 182 (40), 181 (37), 167 (30), 89 (100), 73 (35), 59 (48).

Concentration of fraction B $\left(R_{\mathrm{f}} 0.2\right)$ provided the starting iodide 7 (229 $\mathrm{mg}, 41 \%$ recovery) which was identical, in all respects, to an authentic sample.

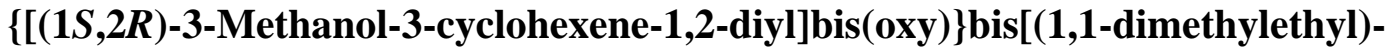

dimethylsilane (20). A magnetically stirred slurry of compound $\mathbf{1 9}^{2}(1.00 \mathrm{~g}, 2.7 \mathrm{mmol})$ and potassium azodicarboxylate $(2.60 \mathrm{~g}, 13.4 \mathrm{mmol})$ in methanol $(13 \mathrm{~mL})$ maintained at $0{ }^{\circ} \mathrm{C}$ was treated, dropwise, with glacial acetic acid $(1.5 \mathrm{~mL}, 26.2 \mathrm{mmol})$. The ensuing slurry was warmed to $18{ }^{\circ} \mathrm{C}$, stirred for $1 \mathrm{~h}$ at this temperature then quenched with $\mathrm{NaHCO}_{3}(100 \mathrm{~mL}$ of a saturated aq solution) and the separated aqueous layer extracted with dichloromethane $(4 \times 40 \mathrm{~mL})$. The combined organic phases were dried $\left(\mathrm{MgSO}_{4}\right)$, filtered and concentrated under reduced pressure to give a light-yellow oil. Subjection of this material to flash chromatography $(5: 95 \mathrm{v} / \mathrm{v}$ ethyl acetate-hexane elution) and concentration of the relevant fractions $\left(R_{\mathrm{f}} 0.3\right.$ in $1: 9 \mathrm{v} / \mathrm{v}$ ethyl acetate-hexane) then gave the title compound $20(745 \mathrm{mg}, 74 \%)$ as a clear, colorless oil, $[\alpha]_{\mathrm{D}}$ +79.1 (c 2.5) [Found: $(\mathrm{M}+\mathrm{Na})^{+}, 395.2408 . \mathrm{C}_{19} \mathrm{H}_{40} \mathrm{O}_{3} \mathrm{Si}_{2}$ requires 395.2408]. $v_{\max }$ (film, $\mathrm{NaCl}) / \mathrm{cm}^{-1} 3358,2953,2931,2858,2892,1468,1388,1363,1264,1062,898,836,775 ; \delta_{\mathrm{H}} 5.82$ $(1 \mathrm{H}, \mathrm{m}), 4.06(2 \mathrm{H}, \mathrm{m}), 3.87(2 \mathrm{H}, \mathrm{m}), 2.20(1 \mathrm{H}, \mathrm{m}), 1.98(1 \mathrm{H}, \mathrm{m}), 1.81(1 \mathrm{H}, \mathrm{m}), 1.65-1.45(2 \mathrm{H}$, complex m), $0.90(9 \mathrm{H}, \mathrm{s}), 0.87(9 \mathrm{H}, \mathrm{s}), 0.14(3 \mathrm{H}, \mathrm{s}), 0.13(3 \mathrm{H}, \mathrm{s}), 0.07(2)(3 \mathrm{H}, \mathrm{s}), 0.07(0)(3 \mathrm{H}$, s); $\delta_{\mathrm{C}} 135.9(\mathrm{C}), 127.2(\mathrm{CH}), 70.5(\mathrm{CH}), 69.2(\mathrm{CH}), 65.9\left(\mathrm{CH}_{2}\right), 25.9\left(3 \times \mathrm{CH}_{3}\right), 25.8\left(3 \times \mathrm{CH}_{3}\right)$, $24.3\left(\mathrm{CH}_{2}\right), 20.6\left(\mathrm{CH}_{2}\right), 18.1(\mathrm{C}), 18.0(\mathrm{C}),-4.2\left(\mathrm{CH}_{3}\right),-4.4(6)\left(\mathrm{CH}_{3}\right),-4.5(1)\left(\mathrm{CH}_{3}\right),-4.5(4)$ $\left(\mathrm{CH}_{3}\right) ; m / z 357\left[\left(\mathrm{M}-\mathrm{CH}_{3} \cdot\right)^{+},<1 \%\right], 341(<1), 339(<1), 315\left[\left(\mathrm{M}-\mathrm{C}_{4} \mathrm{H}_{9} \cdot\right)^{+}, 20\right], 223(79), 183(56)$, 157 (65), 133 (27), 105 (28), 91 (33), 75 (87), 73 (100).

Compounds 21a and 21b. A magnetically stirred solution of compound 20 (429 mg, 1.15 $\mathrm{mmol})$ in methanol $(23 \mathrm{~mL})$ was cooled to $-78{ }^{\circ} \mathrm{C}$ and treated with a stream of ozone until a blue color persisted and TLC analysis indicated the complete consumption of starting material $(\sim 0.25 \mathrm{~h})$. The excess ozone was then removed with a stream of nitrogen and the resulting 
colorless solution was placed in an ice-bath $(10 \mathrm{~min})$ then $\mathrm{NaBH}_{4}(178 \mathrm{mg}, 4.71 \mathrm{mmol})$ added in three portions over $10 \mathrm{~min}$. After addition was complete, TLC analysis indicated the disappearance of the ozonolysis product. As a result the mixture was quenched with $\mathrm{NH}_{4} \mathrm{Cl}(1 \times$ $5 \mathrm{~mL}$ of a saturated aq solution) and extracted with dichloromethane $(3 \times 20 \mathrm{~mL})$. The combined organic phases were then dried $\left(\mathrm{MgSO}_{4}\right)$, filtered and concentrated under reduced pressure to give a viscous and light-yellow oil. This material was subjected to flash chromatography $(1: 3$ $\mathrm{v} / \mathrm{v}$ ethyl acetate-hexane elution) and two fractions, $\mathrm{A}$ and $\mathrm{B}$, thereby obtained.

Concentration of fraction A $\left(R_{\mathrm{f}} 0.3\right.$ in $1: 1 \mathrm{v} / \mathrm{v}$ ethyl acetate-hexane) gave triol 21a (288 mg, $61 \%$ ), of undetermined stereochemistry at $\mathrm{C} 2$, as a clear, colorless oil, $[\alpha]_{\mathrm{D}}-42.6(c$ 1.4) [Found: $(\mathrm{M}+\mathrm{H})^{+}, 409.2795 . \mathrm{C}_{19} \mathrm{H}_{45} \mathrm{O}_{5} \mathrm{Si}_{2}$ requires 409.2800]. $v_{\max }($ film, $\mathrm{NaCl}) / \mathrm{cm}^{-1} 3428,2933,2860$, $1467,1255,1094,835,776 ; \delta_{\mathrm{H}} 4.23(1 \mathrm{H}, \mathrm{s}), 3.80-3.52(7 \mathrm{H}$, complex m), $2.27(1 \mathrm{H}, \mathrm{br}, \mathrm{s}), 1.92-$ $1.68(3 \mathrm{H}$, complex m), $1.52(2 \mathrm{H}, \mathrm{m}), 0.90(9 \mathrm{H}, \mathrm{s}), 0.86(9 \mathrm{H}, \mathrm{s}), 0.14(3 \mathrm{H}, \mathrm{s}), 0.11(3 \mathrm{H}, \mathrm{s}), 0.09$ $(3 \mathrm{H}, \mathrm{s}), 0.07(3 \mathrm{H}, \mathrm{s}) ; \delta_{\mathrm{C}} 76.7(\mathrm{CH}), 72.8(\mathrm{CH}), 70.2(\mathrm{CH}), 63.1\left(\mathrm{CH}_{2}\right), 62.6\left(\mathrm{CH}_{2}\right), 29.9\left(\mathrm{CH}_{2}\right)$, $26.7\left(\mathrm{CH}_{2}\right), 25.6(9)\left(3 \times \mathrm{CH}_{3}\right), 25.6(6)\left(3 \times \mathrm{CH}_{3}\right), 17.8(2 \times \mathrm{C}),-4.1\left(\mathrm{CH}_{3}\right),-4.3\left(\mathrm{CH}_{3}\right),-4.8$ $\left(\mathrm{CH}_{3}\right),-5.0\left(\mathrm{CH}_{3}\right) ; \mathrm{m} / z(\mathrm{ES}) 431\left[(\mathrm{M}+\mathrm{Na})^{+}, 19 \%\right], 409\left[(\mathrm{M}+\mathrm{H})^{+}, 100\right]$.

Concentration of fraction $\mathrm{B}\left(R_{\mathrm{f}} 0.25\right.$ in $1: 1 \mathrm{v} / \mathrm{v}$ ethyl acetate-hexane) gave triol $21 \boldsymbol{b}$ (119 $\mathrm{mg}, 25 \%$ ), of undetermined stereochemistry at $\mathrm{C} 2$, as a clear, colorless oil, $[\alpha]_{\mathrm{D}}-37.3(c 0.8)$. $v_{\max }($ film, $\mathrm{NaCl}) / \mathrm{cm}^{-1} 3396,2932,2859,1468,1255,1099,835,776 ; \delta_{\mathrm{H}} 4.23(1 \mathrm{H}, \mathrm{s}), 3.80-3.40$ $(6 \mathrm{H}$, complex m), $2.48(3 \mathrm{H}$, br s), $1.75(2 \mathrm{H}, \mathrm{m}), 1.47(2 \mathrm{H}, \mathrm{m}), 0.90(9 \mathrm{H}, \mathrm{s}), 0.88(9 \mathrm{H}, \mathrm{s}), 0.11$ $(6 \mathrm{H}, \mathrm{s}), 0.07(6 \mathrm{H}, \mathrm{s}) ; \delta_{\mathrm{C}} 74.5(\mathrm{CH}), 74.1(\mathrm{CH}), 69.6(\mathrm{CH}), 64.9\left(\mathrm{CH}_{2}\right), 62.8\left(\mathrm{CH}_{2}\right), 30.2\left(\mathrm{CH}_{2}\right)$, $27.4\left(\mathrm{CH}_{2}\right), 25.8(0)\left(3 \times \mathrm{CH}_{3}\right), 25.7(9)\left(3 \times \mathrm{CH}_{3}\right), 18.0(2)(\mathrm{C}), 17.9(6)(\mathrm{C}),-4.0\left(\mathrm{CH}_{3}\right),-4.1$ $\left(\mathrm{CH}_{3}\right),-4.6\left(\mathrm{CH}_{3}\right),-4.7\left(\mathrm{CH}_{3}\right) ; \mathrm{m} / z(\mathrm{ES}) 409\left[(\mathrm{M}+\mathrm{H})^{+}, 100 \%\right]$.

Compound 22a. A magnetically stirred solution of triol 21a (296 mg, $0.72 \mathrm{mmol}$ ) and DMAP (530 mg, $4.34 \mathrm{mmol})$ in chloroform $(7 \mathrm{~mL})$, maintained under a nitrogen atmosphere, was cooled to $0{ }^{\circ} \mathrm{C}$ and treated dropwise with thiophosgene $(170 \mu \mathrm{L}, 2.23 \mathrm{mmol})$. The resulting mixture was stirred for $1 \mathrm{~h}$ at $0{ }^{\circ} \mathrm{C}$ then Merck Type 60 silica gel $(\sim 1 \mathrm{~g})$ was added and the ensuing slurry concentrated under reduced pressure to give a free-flowing orange-yellow powder. This material was loaded on a short pad of Merck Type 60 silica gel and eluted with ethyl acetate-hexane $(1: 9 \mathrm{v} / \mathrm{v}$ mixture). Concentration of the filtrate under reduced pressure gave the title compound 22a (204 mg, 60\%), of undetermined stereochemistry at C2, as a yellow gum, $R_{\mathrm{f}} 0.3$ (in $1: 9 \mathrm{v} / \mathrm{v}$ ethyl acetate-hexane), $[\alpha]_{\mathrm{D}}-56.2(c \quad 0.3)$ [Found: $(\mathrm{M}-\mathrm{Cl} \cdot)^{+}, 433.2262 . \mathrm{C}_{20} \mathrm{H}_{41} \mathrm{O}_{4} \mathrm{SSi}_{2}$ requires 433.2264]. $v_{\max }($ film, $\mathrm{NaCl}) / \mathrm{cm}^{-1} 2931,2858,1469,1287,1172,1126,836,777 ; \delta_{\mathrm{H}} 5.19(1 \mathrm{H}$, $\mathrm{m}), 4.72(1 \mathrm{H}, \mathrm{m}), 4.56(1 \mathrm{H}, \mathrm{m}), 4.09(1 \mathrm{H}, \mathrm{d}, J=4.7 \mathrm{~Hz}), 3.58(1 \mathrm{H}, \mathrm{ddd}, J=2.2,4.7$ and 10.5 $\mathrm{Hz}), 3.51(2 \mathrm{H}, \mathrm{m}), 1.98-1.56(4 \mathrm{H}$, complex m), $0.87(18 \mathrm{H}, \mathrm{m}), 0.13(3 \mathrm{H}, \mathrm{s}), 0.09(0)(3 \mathrm{H}, \mathrm{s})$, 0.08(7) $(3 \mathrm{H}, \mathrm{s}), 0.06(3 \mathrm{H}, \mathrm{s}) ; \delta_{\mathrm{C}} 191.1(\mathrm{C}), 81.8(\mathrm{CH}), 73.5(\mathrm{CH}), 72.6(\mathrm{CH}), 68.5\left(\mathrm{CH}_{2}\right), 44.5$ $\left(\mathrm{CH}_{2}\right), 29.6\left(\mathrm{CH}_{2}\right), 28.9\left(\mathrm{CH}_{2}\right), 25.7\left(3 \times \mathrm{CH}_{3}\right), 25.6\left(3 \times \mathrm{CH}_{3}\right), 17.8(2 \times \mathrm{C}),-4.2\left(\mathrm{CH}_{3}\right),-4.6$ $\left(\mathrm{CH}_{3}\right),-4.7\left(\mathrm{CH}_{3}\right),-4.8\left(\mathrm{CH}_{3}\right) ; m / z 433\left[(\mathrm{M}-\mathrm{Cl} \cdot)^{+}, 22 \%\right], 391(10), 355$ (20), 241 (46), 185 (99), 161 (55), 133 (100).

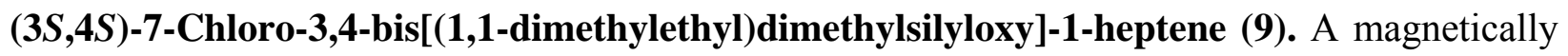
stirred solution of thiocarbonate 22a $(195 \mathrm{mg}, 0.43 \mathrm{mmol})$ in 1,3-dimethyl-2-phenyl-1,3,2- 
diazaphospholidine $(240 \mu \mathrm{L}, 1.3 \mathrm{mmol})$ maintained under a nitrogen atmosphere was heated at $40{ }^{\circ} \mathrm{C}$ for $15 \mathrm{~h}$ then cooled and subjected to flash chromatography (3:97 v/v ethyl acetatehexane elution). Concentration of the relevant fractions $\left(R_{\mathrm{f}} 0.2\right.$ in $2: 98 \mathrm{v} / \mathrm{v}$ ethyl acetatehexane) then gave the title compound $9(106 \mathrm{mg}, 63 \%)$ as a clear, colorless oil, $[\alpha]_{\mathrm{D}}-79.3(c 0.4)$ [Found: $\left(\mathrm{M}-\mathrm{CH}_{3}\right)^{+}, 377.2084 . \mathrm{C}_{18} \mathrm{H}_{38}{ }^{35} \mathrm{ClO}_{2} \mathrm{Si}_{2}$ requires 377.2099]. $v_{\max }(\mathrm{film}, \mathrm{NaCl}) / \mathrm{cm}^{-1} 2955$, 2858, 1468, 1255, 1089, 1031, 835, 774; $\delta_{\mathrm{H}} 5.97(1 \mathrm{H}, \mathrm{ddd}, J=3.9,10.6$ and $17.3 \mathrm{~Hz}), 5.27(1 \mathrm{H}$, $\mathrm{dt}, J=2.2$ and $17.3 \mathrm{~Hz}), 5.16(1 \mathrm{H}, \mathrm{dt}, J=2.2$ and $10.6 \mathrm{~Hz}), 4.16(1 \mathrm{H}, \mathrm{m}), 3.60(1 \mathrm{H}, \mathrm{ddd}, J=$ $3.1,5.8$ and $8.6 \mathrm{~Hz}), 3.52(2 \mathrm{H}, \mathrm{t}, J=6.9 \mathrm{~Hz}), 1.89(1 \mathrm{H}, \mathrm{m}), 1.72(2 \mathrm{H}, \mathrm{m}), 1.43(1 \mathrm{H}, \mathrm{m}), 0.91$ $(9 \mathrm{H}, \mathrm{s}), 0.90(9 \mathrm{H}, \mathrm{s}), 0.08(3 \mathrm{H}, \mathrm{s}), 0.07(3 \mathrm{H}, \mathrm{s}), 0.06(3 \mathrm{H}, \mathrm{s}), 0.05(3 \mathrm{H}, \mathrm{s}) ; \delta_{\mathrm{C}} 136.4(\mathrm{CH}), 114.9$ $\left(\mathrm{CH}_{2}\right), 75.1(\mathrm{CH}), 74.8(\mathrm{CH}), 45.4\left(\mathrm{CH}_{2}\right), 29.7\left(\mathrm{CH}_{2}\right), 28.5\left(\mathrm{CH}_{2}\right), 25.9\left(6 \times \mathrm{CH}_{3}\right), 18.3(\mathrm{C}), 18.1$ (C), -4.1 $\left(\mathrm{CH}_{3}\right),-4.5\left(\mathrm{CH}_{3}\right),-4.6\left(\mathrm{CH}_{3}\right),-4.8\left(\mathrm{CH}_{3}\right) ; \mathrm{m} / \mathrm{z} 379$ and 377 [( $\left.\mathrm{M}-\mathrm{CH}_{3}\right)^{+}$, each <1\%], 337 and $335\left[\left(\mathrm{M}-\mathrm{C}_{4} \mathrm{H}_{9}\right)^{+}, 3\right.$ and 10\%)], 221 (49), 147 (62), 111 (23), 73 (100), 71 (37).

\section{Crystallographic Studies}

Crystal data for 15: $\mathrm{C}_{6} \mathrm{H}_{9} \mathrm{ClO}_{2}, M=148.589, T=200 \mathrm{~K}$, monoclinic, space group $P 2_{1}, Z=6, a=$ 11.1403 (10), $b=6.8090$ (5), $c=14.3356$ (9) $\AA, \beta=106.896(5), V=1040.48$ (14) $\AA^{3}, D_{\mathrm{x}}=1.423$ $\mathrm{Mg} \mathrm{m}^{-3}, 3646$ unique data $\left(2 \Theta_{\max }=50.34^{\circ}\right), 2814$ with $I>3.00 \sigma(I), R=0.034, R_{\mathrm{w}}=0.038, S=$ 0.996 .

Images were measured on a Nonius Kappa CCD diffractometer (MoKa, graphite monochrometer) and data extracted using the DENZO package. ${ }^{14}$ Structure solution was by direct methods (SIR97) ${ }^{15}$ and refinement was by full matrix least-squares on $F$ using the CRYSTALS program package. ${ }^{16}$ Atomic co-ordinates, bond lengths and angles, and displacement parameters have been deposited at the Cambridge Crystallographic Data Centre (CCDC reference number 227945).

\section{Acknowledgements}

Dr Gregg Whited (Genencor International Inc., Palo Alto) is warmly thanked for providing us with generous quantities of compound 7. We gratefully acknowledge Dr Michael Mueller (Forschungszentrum, Juelich) for providing samples of the trans-dihydrocatechol derivative 19.

\section{References}

1. See, for example: Banwell, M. G.; Edwards, A. J.; Harfoot, G. J.; Jolliffe, K. A.; McLeod, M. D.; McRae, K. J.; Stewart, S. G.; Vögtle, M. Pure Appl. Chem. 2003, 75, 223.

2. Lorbach, V.; Franke, D.; Nieger, M.; Mueller, M. Chem. Commun. 2002, 494.

3. Boyd, D. R.; Sharma, N. D.; Barr, S. A.; Dalton, H.; Chima, J.; Whited, G.; Seemayer, R. J. Am. Chem. Soc. 1994, 116, 1147. 
4. For especially useful reviews on the production and synthetic utility of such cis-1,2dihydrocatechols see: (a) Hudlicky, T.; Gonzalez, D.; Gibson, D. T. Aldrichimica Acta 1999, 32, 35. (b) Johnson, R. A. Org. React. 2004, 63, 117.

5. Pasto, D. J.; Taylor, R. T. Org. React. 1991, 40, 91.

6. Banwell, M. G.; Lambert, J. N.; Richards, S. L. Aust. J. Chem. 1991, 44, 939.

7. Boyd, D. R.; Sharma, N. D.; Dalton, H.; Clarke, D. A. Chem. Commun. 1996, 45.

8. Banwell, M. G.; Jolliffe, K. A.; Loong, D. T. J.; McRae, K. J.; Vounatsos, F. J. Chem. Soc., Perkin Trans. 1 2002, 22.

9. Banwell, M. G.; Forman, G. S.; Hockless, D. C. R. Ind. J. Chem. 1999, 38B, 1011.

10. Watkin, D. J.; Prout, C. K.; Pearce, L. J. CAMERON, Chemical Crystallography Laboratory: Oxford, UK, 1996.

11. Kumada, M. Pure Appl. Chem. 1980, 52, 669.

12. (a) Corey, E. J.; Carey, F. A.; Winter, R. A. E. J. Am. Chem. Soc. 1965, 87, 934. (b) Corey, E. J.; Hopkins, P. B. Tetrahedron Lett. 1982, 23, 1979.

13. Still, W. C.; Kahn, M.; Mitra, A. J. Org. Chem. 1978, 43, 2923.

14. DENZO-SMN. Otwinowski, Z.; Minor, W. Processing of X-ray diffraction data collected in oscillation mode. In Methods in Enzymology, Volume 276: Macromolecular Crystallography, Part A; Carter Jr., C. W.; Sweets, R. M., Eds. Academic Press: New York, 1997; pp 307326.

15. Altomare, A.; Burla, M. C.; Camalli, M.; Cascarano, G. L.; Giacovazzo, C.; Guagliardi, A.; Moliterni, A. G. G.; Polidori, G.; Spagna, R. J. Appl. Crystallogr. 1999, 32, 115.

16. Watkin, D. J.; Prout, C. K.; Carruthers, J. R.; Betteridge, P. W.; Cooper, R. I. CRYSTALS Issue 11, Chemical Crystallography Laboratory: Oxford, UK, 2001. 